\title{
Essential Corporate Bankruptcy Law
}

\author{
Oscar Couwenberg • Stephen J. Lubben
}

Published online: 31 March 2015

(C) The Author(s) 2015. This article is published with open access at Springerlink.com

\begin{abstract}
This article begins from a simple observation: Chapter 11 of the United States Bankruptcy Code is the global standard for corporate restructuring, but at the same time it is a far more complex procedure than most jurisdictions seem to require. This observation begs the question what parts of a bankruptcy system are 'essential'. We argue that two elements are essential because they cannot be achieved by contracting alone: asset stabilisation and asset separation. Stabilisation ensures that the firm's options are maintained. Asset separation ensures that the assets underlying these options can be separated from liabilities that are attached to them by law or contract. Both these elements drive much of the rules that are necessary to resolve distress but also show that parts of Chapter 11 are 'unessential' - for example, rules regarding reorganisation plans. Our goal is not to doubt the 'richness and elasticity' of corporate bankruptcy, particularly in the United States, but to find the essential elements. Beyond asset stabilisation and asset separation, features of the system are a matter of policy and politics. Understanding this helps in structuring insolvency systems and shows that Chapter 11 need not be the standard against which all other laws are measured.
\end{abstract}

Earlier versions of this paper were presented at the 2013 European Law and Economics Annual Meeting, held at the University of Warsaw, and the 25th Workshop in Law and Economics at the University of Erfurt, and the paper greatly benefited from the comments received. Specifically, we thank Anthony Casey and Michael Simkovic for helpful comments.

O. Couwenberg $(\bowtie)$

Professor of Law and Economics

Department of Law and Economics, Faculty of Law, University of Groningen, Groningen,

The Netherlands

e-mail: o.couwenberg@rug.nl

S. J. Lubben

Harvey Washington Wiley Chair in Corporate Governance \& Business Ethics

Seton Hall University School of Law, Newark, NJ, USA

e-mail: stephen.lubben@shu.edu 
Keywords Bankruptcy law $\cdot$ Reorganisation $\cdot$ Financial distress

\section{Introduction}

In every developed economy, and in most developing economies too, the question of what to do with financially distressed businesses is a matter of concern. ${ }^{1}$ The United States has a long history of corporate restructuring law, starting with the reorganisation of railroads in the nineteenth century ${ }^{2}$ and continuing through Chapter $11^{3}$ in its current form. ${ }^{4}$ This naturally leads to a tendency to adopt Chapter 11 , or something like it. ${ }^{5}$

But why? In particular, Chapter 11 is a rather ornate system of corporate reorganisation. ${ }^{6}$ And in recent years it has been adorned with elements that reflect little more than particular creditors' ability to successfully lobby Congress. ${ }^{7}$ During the early years of Chapter 11, many critics called for its repeal, arguing that it could easily be replaced by contract or elements of basic corporate law. ${ }^{8}$ In recent years, many of these same critics came to herald Chapter 11 as an efficient way to transfer assets to new owners. ${ }^{9}$

So, does Chapter 11 provide something that could be achieved by contract, or does it do something more? That is, does Chapter 11 provide something that could not be achieved by contract? ${ }^{10}$ And does all of Chapter 11 serve this function?

In short, what, if any, are the essential elements of corporate bankruptcy law? ${ }^{11}$

We offer an answer to that question here, arguing that two elements of Chapter 11 are essential: asset stabilisation and asset separation. These two aspects of Chapter 11 could not be established other than by statute. ${ }^{12}$

Asset stabilisation refers to the ability to temporarily protect assets as a coherent whole. It includes obvious things like the stay on individual creditor collection, but

\footnotetext{
${ }^{1}$ Bebchuk (1988), at p. 776.

${ }^{2}$ Lubben (2004) (discussing the history of corporate restructuring in the United States, which initially featured extensive involvement of investment bankers like JP Morgan) and Markell (1991), at pp. 74-77.

${ }^{3}$ United States Bankruptcy Code, 11 U.S.C. $\S \S 1101-1174$.

${ }^{4}$ Warren and Westbrook (2009), at pp. 612-40. Cf. Clark (1981), at pp. 1250-54.

5 Westbrook (2000), at pp. 2278-79 nn. 2-15 (detailing bankruptcy reform efforts throughout the world); see also Eisenberg and Sundgren (1997) and Eisenberg and Tagashira (1994).

${ }^{6}$ LoPucki and Whitford (1990), at p. 126.

7 See Lubben (2012a), Ondersma (2013), at p. 111, Roe (2011) and Simkovic (2009), at p. 253.

${ }^{8}$ Baird (1993), Rasmussen (1992), Roe (1983), at p. 559, and Skeel (1994).

9 Ayotte and Skeel (2006), Baird and Rasmussen (2002a) and Skeel (2003), at p. 918. Some then backed away from their embrace of the new order following the GM and Chrysler Chapter 11 cases. See Roe and Skeel (2010).

${ }^{10}$ Cf. Romano (1989), at p. 1599.

${ }^{11}$ See generally Hansmann and Kraakman (2000) (asking a similar question with regard to state corporate law). In this paper, we posit that corporate bankruptcy law is or should be seen as an integral part of organisational law, but we focus on a subset of organisational law that Hansmann and Kraakman neglected.

12 Others, of course, disagree. E.g., Schwartz (1998), at p. 1851.
} 
also other features, such as the ability to provide post-bankruptcy liquidity to the debtor and delays on termination of contracts with the debtor.

Asset separation captures the ability to separate assets from their concomitant liabilities. This might take the form of a discharge, but we argue that, strictly speaking, a discharge is not necessary to achieve asset separation.

Despite two decades of corporate scholarship, and countless overheated debates on the merits of Chapter $11,{ }^{13}$ neither of these two aspects of corporate bankruptcy have been the focus of commentary or analysis to date. ${ }^{14}$

\section{Financial Distress and Firms}

Firms encounter financial distress for myriad reasons. One firm's business model might be fatally flawed: it has an interesting idea, but can never make money pursuing it. Another firm might have assets that are out of scale with its business, such as the airline that has more planes than it needs to serve its customers. And yet another firm might be quite viable but for the debt it acquired in a leveraged buyout. Often, it will not be immediately apparent at the point of distress what type of debtor a particular firm is.

The firm itself is a package of assets - broadly defined to include employees and other factors that contribute to firm value. ${ }^{15}$ The literature regarding particular firm structures and their governance is well developed, but not particularly vital to our discussion. ${ }^{16}$ Instead, we focus on the general notion that a firm is comprised of an isolated group of assets that are subject to a variety of claims.

As a result of these claims, and the formal and informal power that the claimants possess with regard to the firm, a distressed firm is particularly likely to be the subject of competing impulses regarding future courses of action. ${ }^{17}$

Outside of financial distress, the resolution of these competing demands is relatively straightforward. As a matter of formal law, firms typically have a defined governance body that coordinates action. ${ }^{18}$ In the case of a corporation, this is the board, and historically the most junior claimants elect the firm's board, at least in for-profit firms. ${ }^{19}$ In times of financial distress, the governance mechanism remains in place, but the membership might change and the ability to control governance becomes a point of contention. ${ }^{20}$

\footnotetext{
13 Easterbrook (1990), LoPucki (1992), Skeel (1993), Warren (1993) and Warren and Westbrook (2005).

14 More typically, the classic literature has focused on Chapter 11 as a solution to collective action problems. Baird and Jackson (1984, 1988), Jackson (1982), Jackson and Scott (1989), at p. 176, and Scott (1986).

15 See Warren (1992), at p. 468.

16 See, e.g., Bainbridge (2003), at p. 564-65; Bratton (1989), at p. 415; Dodd (1932), at pp. 1155-56; Fish (2010) and Stout (2007), at pp. 804-05.

17 Jackson and Scott (1989), at pp. 177-78.

18 Del. Gen. Corp. Law. $\$ 141$ (a) ('The business and affairs of every corporation organized under this chapter shall be managed by or under the direction of a board of directors...').

19 Hansmann and Kraakman (2001), at p. 442.

${ }^{20}$ See Hu and Westbrook (2007), at pp. 1331-48, and Tung (2009), at p. 117.
} 
Corporate bankruptcy provides a mechanism for resolving these competing claims, and does so by allowing asset stabilisation and asset separation. Stabilisation ensures that the firm's operational options are maintained. Asset separation ensures that the assets underlying these options can be separated from liabilities that by law or contract are attached to them.

Both these functions are to be seen within the realm of organisational law, of which, in our view, corporate bankruptcy is part and parcel. ${ }^{21}$

Organisational law provides the format in which the economic activities of firms are set and has many aims - one of which is to protect the specific pool of assets against claims by creditors of the owners (affirmative asset partitioning) and another to delineate that pool by prohibiting creditors of the firm to grab assets of the owners (defensive asset partitioning). ${ }^{22}$ Affirmative asset partitioning keeps the assets together. It is the legal acknowledgment of the main insight of economic organisation theory that assets brought together in a firm are what makes firms valuable in the first place. ${ }^{23}$

It is also the main and most important reason why corporate bankruptcy is different from consumer bankruptcy law. ${ }^{24}$ In a consumer bankruptcy, keeping assets together is not as important since the income-generating asset - the indebted consumer, who is also an employee or an entrepreneur - cannot be stripped from his or her abilities. ${ }^{25}$ In a corporate bankruptcy, firms can easily be stripped of their assets, in the process destroying any existing synergies.

To be sure, firms err in bringing assets together; they get too big, too small, too diversified, and it is competition that gets these firms back in line, or ultimately leads them to bankruptcy. ${ }^{26}$

Corporate bankruptcy law adds to affirmative asset partitioning the protection of the integrity of the asset pool itself. Given the conscious decision of the firm's management to bring this particular constellation of assets together, negating that decision upon financial distress would destroy any asset synergies.

This is the function of asset stabilisation in bankruptcy law. It should be noted that it is superfluous outside bankruptcy. It is the board of directors that decides upon a specific collection of assets and it is this same board that decides to keep it this way or alter it. ${ }^{27}$ A protective function like asset stabilisation is thus not needed in general organisational law. ${ }^{28}$

\footnotetext{
${ }^{21}$ Cf. Skeel (1994), at pp 506-07.

22 See Hansmann and Kraakman (2000) for further refinements.

23 Obviously, this builds upon the arguments Ronald Coase put forth in 1937, see Coase (1937).

${ }^{24}$ Conceding, of course, that sometimes the distinction is elusive in the case of small businesses. Lawless and Warren (2005), at p. 768.

25 Baird (1987a), at p. 182.

26 E.g., Baird (1998), at p. 580.

27 E.g., Del. Gen. Corp. Law $§ 271$ (requiring board approval to commence asset sales).

28 A case in point is when assets are not pooled at all, but allocated to different corporations. See Baird and Casey (2013). As with bringing assets together, a (legal) separation of them is also to be seen as a conscious decision. Obviously, the aim is to circumvent the asset stabilisation regime in bankruptcy proceedings.
} 
Once in distress, however, the board no longer has sole decision-making authority over the assets, as creditors' rights are triggered by the initiation of a bankruptcy procedure or some other indicator of distress. ${ }^{29}$

These rights can lead to the break-up of the asset pool, which may happen in two ways. First, certain creditors may, by contract, have a claim that enables them to withdraw and sell specific assets out of the pool to satisfy their claims, without any obligation to take synergistic losses into account. ${ }^{30}$ Second, creditors may try to better their position by grabbing assets out of the pool, as permitted by debt collection law. ${ }^{31}$ Both lead to destruction of the pool of assets, hence the need for asset stabilisation in bankruptcy. ${ }^{32}$

The second form of asset partitioning, defensive asset partitioning, keeps other pools of assets together: creditors of the firm are not allowed to destroy pools of assets that belong to the firms' owners.

The asset separation function of bankruptcy law works in a similar vein, only it focuses on the assets in the firm's asset pool. Where defensive asset partitioning separates assets of owners from the firm, bankruptcy law's asset separation separates the firm's assets from claims of creditors on those assets.

This separation differs from asset stabilisation in that the assets are not protected by the delaying of creditor claims on specific assets, but rather it allows the assets to be sold without any claim of any creditor on those assets attached.

In this sense, bankruptcy law transforms a claim on a particular asset into a tortlike claim for monetary compensation equal to the value of the asset. The main value-enhancing effect of this separation is that it makes the sale of assets easier to effectuate, thus minimising value destruction during financial distress. ${ }^{33}$

Prospective buyers need not inquire into the nature of the attached creditor claims and are free to do with the asset whatever they think is best. This provides a setting in which prospective buyers can bid their private full value of the asset, without the need to value the obligations attached to it, maximising the returns to the estate.

Again, outside bankruptcy, a sale of assets is the sole province of the board of directors, although contractual obligations imposed by a lender may limit this discretion. In this setting, the decision to sell a key asset implies that a bilateral agreement has been reached between the board of directors and the relevant creditors. ${ }^{34}$ Consent can be assumed to have a price, and produce incentives for hold-out strategies.

With the initiation of bankruptcy, asset separation enables the bankruptcy controller to choose that deal that benefits the estate the most, instead of relegating that decision to a particular creditor. In most cases, such a creditor will lack the

\footnotetext{
29 Baird and Rasmussen (2006), at p. 1211.

30 See U.C.C. $\$ 9-503$.

31 See U.C.C. $\$ 9-501$.

32 This shows that it is not only a common pool problem that is the foundation for bankruptcy law, as is assumed in the creditors' bargain theory of bankruptcy. See Baird and Jackson (1988).

33 Baird and Rasmussen (2002b), at p. 1805.

34 Baird and Rasmussen (2003), at p. 675.
} 
knowledge or the incentive to find out what particular sets of assets are best packaged and sold together.

Asset stabilisation and asset separation are both needed to operate a bankruptcy system. Stabilisation without separation and vice versa leads to inefficient results.

Without separation, stabilisation alone would make the asset sale inefficient. The bankruptcy controller would not be able to sell the assets in the optimal package. Creditors would try to extract privileges or rents to remove liens or attachments to specific assets, effectively prolonging the procedure, diminishing asset values and lowering returns to the estate. In this bargaining process, the value difference between piecemeal liquidation and going-concern asset sale would be subject to rent-seeking by each creditor. Any deal done by the bankruptcy controller with a specific creditor would yield the next creditor a higher hold-out value.

Without stabilisation, separation alone would lead to an inefficient deployment of assets. The bankruptcy controller would not be able to keep assets together or in operation, thus making it more difficult to sell assets at a going-concern premium. He would have to revert to a piecemeal liquidation of the estate, or at the very least a rushed sale of the estate. ${ }^{35}$ Without stabilisation, asset separation can then add only little value to the estate.

Both asset stabilisation and separation are necessary additions to organisational law. Where organisational law protects pools of assets from creditor interference outside a specific legal form, bankruptcy law protects assets within a specific legal form, but it does so only in bankruptcy as outside bankruptcy it is the board of directors that is responsible for the protection of the firm's assets. Even more importantly, these two functions are the necessary and sufficient ingredients for a bankruptcy law system to operate efficiently. The two are essential elements of bankruptcy law.

\section{Stability and Separation by Contract?}

In this section we show why it would be impossible to erect the two essential elements of bankruptcy law with contracts. As will be shown, while asset stabilisation and separation could be constructed voluntarily under highly stylised conditions, under anything approaching real-world conditions the costs of doing so would be prohibitive and the likelihood of doing so would be doubtful.

The literature on incomplete contracting identifies three elements that yield a non-contractable situation: unobservability, unverifiability and unenforceability. The elements are not necessarily cumulative. ${ }^{36}$ Under this literature, only if it is impossible or very costly to use a contractual solution is it absolutely necessary to invoke bankruptcy law. ${ }^{37}$

\footnotetext{
35 Picker (1992), at p. 528.

36 See generally Hart (1995). We deem these factors sufficiently malleable to cover practical concerns not originally addressed by the literature.

37 Adler (1993), at p. 314. But see Warren and Westbrook (2005), at pp. 1253-54. For purposes of this paper, we take no position as to whether this minimalist position is right as a matter of policy.
} 


\subsection{Asset Stabilisation by Contract}

In general, any contractual solution to financial distress will always fall down when addressing involuntary creditors. ${ }^{38}$ And while the typical response is to assume such creditors should receive some sort of priority, such a solution ignores important ways in which priority of payment can be defeated. ${ }^{39}$

Even if we focus solely on contractual creditors, to generate asset stabilisation by contract all creditors would need to waive their individual contractual rights to specific assets in order to keep the assets together. Creditors would so contract if a series of unrealistic assumptions held, namely:

- All creditors believe that the debtor's assets are worth more as a whole;

- All creditors agree on the value of the assets;

- All creditors believe they will recover more by collective action.

If all three conditions hold, no creditor will disrupt the collective proceeding and a contractual solution will exist.

It is here that the problems of a contractual solution manifest themselves. ${ }^{40}$ Of course, it is improbable that different types of creditors will have homogeneous expectations concerning the value of the firm. ${ }^{41}$ Even if they did, we should expect that any such moment of agreement would be fleeting.

After all, if the market for the debtor's claims is even somewhat liquid, such agreement cannot long persist if the market is to keep functioning. But even when claims are not traded, it is very unlikely that the expectations will stay homogeneous as the prospects of the firm change. With that, agreement will break down as well.

Moreover, equal access to information would be vital to such a contract. ${ }^{42}$ It is not hard to envisage the situation in which a creditor calls upon a court to argue that misrepresentation or changes in the firm's outlook voids the contract. ${ }^{43}$ Whether such a claim is actually true or inspired by opportunistic motives is not important. Such statements are unverifiable in court as the 'true' value of the firm is unobservable. ${ }^{44}$

Furthermore, writing a clause in the contract that any creditor breaking the contract needs to compensate all others for the value lost is problematic. In such situations, the 'true' value of the firm is counterfactual, and thus unobservable, unverifiable and unenforceable. Given these ex post problems, creditors will not be

\footnotetext{
$\overline{38}$ Warren (1992), at p. 472. See also Hansmann and Kraakman (1991).

39 Ben-Ishai and Lubben (2012) (arguing that asset sales in bankruptcy can be used to defeat priority claims).

40 See Altman (1993), at p. 10.

41 Cf. Jackson and Scott (1989), at p. 158 ('A primary objective of any bankruptcy process is to regulate the inherent conflicts among different groups having separate claims against a debtor's assets and income stream').

42 See LoPucki (1992), at pp. 81-82.

43 See LoPucki and Whitford (1990), at pp. 194-95.

44 See Bebchuk and Chang (1992), at p. 273.
} 
able to construct a contract ex ante that incorporates such a shared belief concerning the value of the firm.

Even if such a contract were feasible, creditors would have to monitor the debtor firm and provide for monitoring of their fellow creditors. The debtor firm, or more exactly its controlling authority, needs to make the correct economic decisions, while creditors need to be monitored so that no one creditor breaks the contract by extracting assets from the firm. Although the contract may specify the decisions the controller is empowered to make, it is impossible to specify all kinds of important operating decisions that need to be made by the controller.

The controller needs implicit or residual control rights in order to run the firm. But creditors will be sceptical of this power. Decisions not provided for by the express terms of the contract need to be communicated to creditors together with the details that show that the decision was the correct one.

Apart from the inordinate amount of information that would need to be shared, the effect this information would have on expectations concerning firm value is not predictable. It could provide room for any creditor to demand renegotiation or otherwise void the contract.

Monitoring also implies a sharing of information among creditors concerning firm decisions and creditor decisions about contract compliance. ${ }^{45}$ With an increase in the number of creditors and the types of creditor contracts involved, this information sharing becomes increasingly costly and unwieldy. Hence, the apparent need for representation within the firm. However, representation adds a layer to the decision-making structure among creditors and gives rise to additional information asymmetries and agency problems, effectively undermining the benefits of contracting. ${ }^{46}$

The final item bulleted above - that each creditor knows he will receive no less than what he would receive when acting on his own - mimics the actual Chapter 11 rule known as the 'best interest of the creditors' test. ${ }^{47}$ But it is difficult to enforce this rule in a contractual setting.

It is built upon a counterfactual observation - the going-concern value or the liquidation value of the specific asset. ${ }^{48}$ Although one can estimate this value, these estimates are imprecise and vulnerable to manipulation. And these values fluctuate over time due to wear and tear, technological changes and the economic cycle.

In short, asset stabilisation is, at a minimum, costly, or even prohibitively costly, to organise by contract. If asset stabilisation is essential to solving corporate financial distress, as we argue, it then has to be done by statutory law. Although these arguments show that it is costly to organise by contract, they do not necessarily show that statutory law is the solution.

\footnotetext{
$\overline{45}$ Cf. Lipson (2011), at p. 1093.

46 One solution to this problem is to convert all creditor claims to equity. But one should note that this requires a certain amount of mandatory regulation in order to solve priority issues among creditors and asset valuation problems. At this point, the inquiry is to find out reasons why contracts cannot solve this problem, not which type of regulation can solve that.

47 11 U.S.C. $\$ 1129(\mathrm{a})(7)$.

48 Baird and Jackson (1984), at pp. 118-19.
} 
For example, Robert Rasmussen has famously argued that corporate debtors should pick a bankruptcy system ex ante by way of their corporate charter. Debtors would be able to choose from Chapters 7 and 11 but could also waive bankruptcy entirely or devise their own system. ${ }^{49}$

A bankruptcy system in the corporate charter avoids many of the problems of contracting, but still suffers from several key problems. Most notably, what if the debtor actually engages in fraud, representing the firm as a type that would benefit from a form of bankruptcy that results in lower interest rates today, when some other form of bankruptcy would actually better suit the firm and its creditors ex post? What would stop creditors from overturning their prior selection by litigation, and if such fraud were proven, how would a new bankruptcy system be chosen?

Once the fraud was exposed, the benefits of making the choice ex ante would be gone, and the creditors' interests would have become sufficiently diffuse so as to make consensus on a replacement bankruptcy system impossible. Rasmussen allows for the possibility of mid-stream changes to the corporate charter, but only with the unanimous consent of creditors, a solution that seems destined to leave the firm mired in hold-out problems. ${ }^{50}$

Statutory law runs into many of the same problems as contracts, or charters, but its advantage is that it forces an imperfect solution on participants. That is, participants lose their option to exit the arrangement through litigation, since the arrangement is mandatory rather than voluntary. ${ }^{51}$

\subsection{Asset Separation by Contract}

Similarly to asset stabilisation, in order to replicate asset separation by contract, creditors need to agree ex ante to release all rights in the debtor's assets upon sale. This release would need to include not only the obvious - liens - but also claims like fraudulent transfer actions and successor liability rights.

The controller needs to have the power to decide what, when and at what price to sell. For that he needs to have the ability to sell those assets free of any creditor claims. If not, he will be restricted in performing his duties and miss potential valuemaximising offers.

Such freedom of action, though, generates an important agency problem the moment the controller enters the stage. ${ }^{52}$ The controller may decide to sell all valuable assets at artificial low prices to a company owned or controlled by him or

\footnotetext{
49 Rasmussen (1992), at p. 107.

${ }^{50} I d$., at p. 118. In a footnote on the same page, Rasmussen discounts the possibility of hold-out problems, but only by assuming a unity of interest among creditors with regard to the choice of bankruptcy system. Id., at n. 269. Given the varied interests of creditors, this simplifying assumption seems implausible. The infighting among senior creditors in the Chrysler case provides but one recent illustration. In re Chrysler LLC, 405 B.R. 84, 102 (Bankr. S.D.N.Y. 2009) aff'd, 576 F.3d 108 (2d Cir. 2009) cert. granted, appellate judgment vacated as moot, Indiana State Police Pension Trust v. Chrysler LLC, 558 U.S. 1087 (2009) and In re Chrysler, LLC, 592 F.3d 370 (2d Cir. 2010).

51 More than 70 years ago, Max Radin argued that involuntary imposition of a solution upon dissenting creditors was the one basic element of any bankruptcy system. Radin (1940), at p. 7.

52 See LoPucki and Whitford (1993), at pp. 683-84.
} 
any other preferred party. These sorts of fraudulent transactions would seriously undermine the contractual agreement creditors need to reach among themselves.

To prevent such fraud, the controller needs to be restricted to asset sales that provide at least the present value of the claims against the assets, while assuring creditors that they could do no better when acting on their own. ${ }^{53}$ Such an assurance prevents an opportunistic sale of assets by the controller.

He needs to present a better deal than anyone else might present. This requires information concerning the value and price of the assets to be sold and whether the offer is the best one on the table and that no creditor has a better alternative. As with asset stabilisation, this information needs to be shared and creditors need to form homogeneous perceptions in order to agree with the deal. ${ }^{54}$

Although such a contract may prevent an opportunistic sale by the controller, it opens up the possibility of opportunistic hold-up by creditors. This is especially so when a creditor might indeed fetch a higher price for a particular asset but the set of assets together fetches an even higher price. Obviously, a bargain might be struck by transferring part of this premium to that specific creditor. This transfer is ex post efficient, but it generates an incentive for other creditors to hold out as well.

The main source of this problem has been discussed above with regard to asset stabilisation: it presupposes that the asset values can be established and agreed upon among the creditors. In short, asset separation is at best very costly to construct by contract.

One further, global element to consider in discussing the contractual solution is the cost of drafting the contract. The discussion above points out that this drafting will be a complex assignment, yielding a document that might be either wafer-thin providing ample residual decision-making power for the controller - or massively large - documenting all possible contingencies, information-sharing responsibilities and penalties for voiding it.

The wafer-thin version implies a very robust ex post governance mechanism to settle diverging expectations, handle opportunistic actions and provide information. The vastly large one implies a very robust monitoring system to make sure everybody is living up to the contractual obligations. But other costs come up as well with regard to a fully specified agreement.

First, someone must do the drafting. The most obvious candidate is the board. ${ }^{55}$ However, from the creditors' perspective, the board is not an impartial agent in the drafting process at the beginning of the contractual relation, and certainly not at the moment of financial distress. The board will have its own agenda, motives and incentives, which might be at least partly antagonistic to at least certain types of creditors.

Furthermore, this contract must be accepted by all new creditors that interact with the firm. These drafting costs have to be added to the total cost of the contractual solution.

\footnotetext{
53 This latter element is a copy of the agreement creditors have to reach for asset stabilisation.

54 Skeel (1993), at p. 507.

55 Obviously, the board will delegate the actual drafting to agents, but in the text we assume that such agents fully reflect the interests of their principals.
} 
In short, the contractual alternative exists largely as a thought experiment. For any real firm, with a real capital structure, the impossibility of achieving asset stabilisation and asset separation by contract seems self-evident.

\section{Essential Elements of Corporate Bankruptcy Law}

Having thus demonstrated that asset stabilisation and asset separation must be established by statute, we next turn to the aspects of bankruptcy law that support these two essential elements. There are many features of Chapter 11 and other corporate bankruptcy systems that are prominent, even convenient. But we argue that they are not all essential to the basic functioning of corporate bankruptcy law.

We first consider the elements that are necessary to achieve asset stabilisation before turning to asset separation.

\subsection{Asset Stabilisation}

Most obviously, to achieve asset stabilisation individual creditor action must be thwarted. ${ }^{56}$ This means that a collective procedure superseding and subsuming individual actions is essential. In addition, the statute must guarantee that no one gets better treatment than contractually bargained for.

\subsubsection{A Stay on Creditors}

The collective process most often supplants individual creditor rights by imposing a stay. For example, the filing of a bankruptcy petition often creates a bankruptcy estate, from which collective recoveries are paid. ${ }^{57}$ The viability of that estate is then preserved by an automatic stay imposed by statute on all creditors within the jurisdiction of the bankruptcy court. ${ }^{58}$

But the duration of the collective procedure and the stay varies by jurisdiction. Asset stabilisation could be achieved by a judicial stay, ${ }^{59}$ or by transfer of the assets to some new, protected entity. ${ }^{60}$ While exceptions to the prohibition on individual action are inevitable - nobody would support insolvency as an exemption from general criminal law - these exceptions must be drawn as narrowly as possible. ${ }^{61}$

Broad exceptions to the collective process ultimately undermine the process and encourage overinvestment in evasion. ${ }^{62}$ Moreover, at a policy level a jurisdiction needs to decide whether there should be a collective process or not. Broad exceptions to the process, like the exemption of secured creditors that exists in many

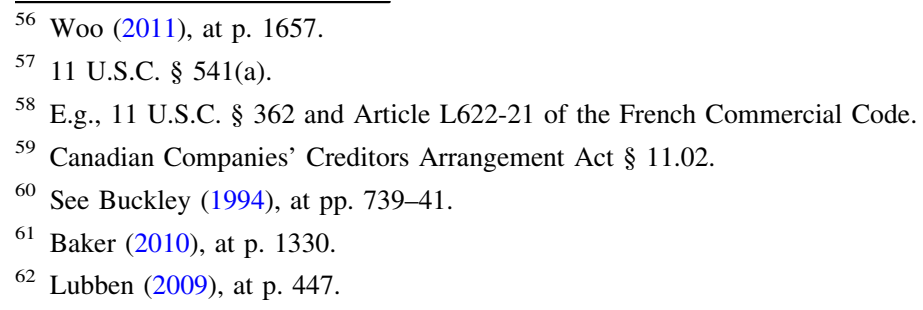


jurisdictions, amount to a waiver of the collective process, especially when the creditor in question has a claim on vital assets. ${ }^{63}$

While it is sometimes suggested that a creditor with a claim on all the debtor's assets will have the proper incentives to consider their value as a whole, this only holds for creditors with claims at the edge of the debtor's going-concern value. If we instead assume that senior creditors routinely over-collateralise their position, then they have no incentive to consider possible externalities that their collection actions will create. Rather, the creditor will prefer the collection method that minimises cost while still resulting in full recovery. This may or may not impair overall efficiency. ${ }^{64}$

An additional inefficiency here results from an oversecured creditor's ability to provide additional financing to the debtor firm. The creditor then eats into the surplus in collateral value that is available to other creditors. This leads to a less timely petition for bankruptcy protection. ${ }^{65}$ And if bankruptcy law is essential for stabilising asset values, doing so sooner rather than later is likely to result in an efficiency gain.

Moreover, even if the creditor is under-collateralised but has a claim on a vital asset, an exception to the collective process allows the creditor to extract rents from other, more junior creditors. The exception gives the preferred creditor the ability to threaten the recoveries of other, junior creditors and thus demand part of their recovery. It seems doubtful as a matter of policy that extortion of this sort should be facilitated by insolvency law.

Asset stability is also promoted by discouraging runs on the debtor's assets. ${ }^{66}$ Thus, many reorganisation systems provide that claims paid in the days before formal proceedings are commenced will be treated as part of the proceedings. ${ }^{67}$ This prevents claimants' efforts to effectuate a socially inefficient, but personally efficient collection of the debtor's assets.

But stopping individual action is not sufficient to achieve asset stabilisation.

Asset stability also requires prohibitions on contractual efforts to undermine the collective process. ${ }^{68}$ Contractual penalties, insolvency termination rights, or creditor protections that activate only upon commencement of the insolvency process have the same effect as creditor efforts to extract individual assets from the debtor.

\footnotetext{
${ }^{63}$ E.g., the Dutch Bankruptcy Law exempts secured creditors from the procedure (Art. 57).

${ }^{64}$ Ayotte and Morrison (2009).

${ }^{65}$ Couwenberg and Jong (2006), provide empirical evidence of such over-collateralisation and financing outcomes in a liquidation-based bankruptcy system. The other side of the coin is that financing is potentially more expensive when a system is geared towards reorganisation.

${ }^{66}$ Countryman (1985), at p. 748.

67 See 11 U.S.C. $\$ 547$ (providing that debtors may recover preferential transfers). See also Article 134 of the Icelandic Bankruptcy Act and UK Insolvency Act 1986, Section 239.

${ }^{68}$ See Schwarcz (1999), at p. 552.
} 


\subsubsection{Funding Liquidity Needs}

Liquidity is also an inevitable prerequisite to maintaining asset values in most firms. ${ }^{69}$ Employees who continue working for the firm must receive their pay packets, vendors' invoices must be paid and assets must be maintained.

Some of the debtor's liquidity needs can be met by foregoing interest payments to bondholders, but suppliers not operating under long-term contracts will make it clear that future deliveries will require cash on delivery, or other forms of security, if the delivery comes at all. That is, the debtor's increasing need for cash often swamps the benefit of suspending debt payments.

Thus, to achieve asset stability the insolvency system must provide for the liquidity needs of the debtor firm. ${ }^{70}$ At minimum, this element of the insolvency system must provide that post-insolvency claims are entitled to priority over preinsolvency claims.

Without this basic protection, new money would benefit old creditors, making such new injections of cash extremely unlikely. ${ }^{71}$ Thus, the system must provide both temporal priority and priority as to rights in specific debtor assets.

Providing priority in the debtor's assets necessarily unleashes several other questions that turn on the basic question of 'how far should this go?' For example, in the United States it is impermissible to provide priority rights in a piece of collateral if doing so will make a prior creditor uncollateralised. ${ }^{72}$ It is thought that such treatment is required by the Fifth Amendment to the Constitution, which protects property from being taken by the government without just compensation.

Other jurisdictions may prioritise creditors in different ways. In a general sense, the key question is one of balancing the benefits of any subordination ex post against the likely ex ante effects. ${ }^{73}$ Conversely, and probably more commonly, many jurisdictions presently provide post-bankruptcy funding with a payment priority, but no security interest in the debtor's assets.

Stabilisation also requires recognition of the soft power that many claimants have with regard to debtors. ${ }^{74}$ Employees may refuse to work if their past claims are not addressed. Trade creditors may legally withhold future inputs if they have no contractual obligation to make future deliveries. ${ }^{75}$ And creditors in foreign jurisdictions might ignore prohibitions on individual creditor action. The liquidity that is used to stabilise the business may also be needed to addresses these issues if doing so will preserve the overall value of the estate. ${ }^{76}$

\footnotetext{
69 Resnick (2005), at p. 185.

70 Lipson (2009), at p. 1621.

71 Myers (1977).

7211 U.S.C. $\$ 364(d)(1)(B)$. See also the Canadian equivalent at Companies' Creditors Arrangement Act $\S 11.2$.

73 Rasmussen (1992), at pp. 64-65.

74 Lubben (2005), at pp. 857-58.

75 In re Just for Feet, Inc., 242 B.R. 821, 825 (Bankr. D. Del. 1999).

76 See Dickerson (2009), at p. 910.
} 


\subsubsection{Distribution Rules}

Addressing liquidity needs, especially when considered in light of the soft power that creditors might possess, will often lead to changes in the normal liquidation distribution scheme. For example, while the United States nominally follows the 'absolute priority rule' in both Chapter 7 and Chapter 11, in Chapter 11 the decision to assume contracts or pay providers of vital inputs will result in full payment of those claimants despite what they might have been entitled to in a liquidation. This suggests a point to which we return in our discussion of asset separation below: namely, that the distribution rules for reorganisation might necessarily deviate from those of liquidation.

The reorganisation system might incorporate the broader set of distribution rules, with possible deviations specified as needed to achieve the specific goals of reorganisation. For example, in the United States, a debtor who wants to assume a currently beneficial contract must cure any past defaults. This has the effect of granting the counterparty better treatment than other unsecured claimants, since its claims get paid in full. ${ }^{77}$ In essence, if the debtor wishes to treat the contract as an asset, rather than a claim for damages, he must fully perform on the contract. ${ }^{78}$

In liquidation such a rule represents a policy judgment that the gains from the contract should be shared among all creditors, rather than conferring a windfall on the counterparty that would otherwise obtain a right to terminate. ${ }^{79}$ In reorganisation, such a rule avoids the going-concern value destruction that could result from termination of agreements, especially given that such value destruction is apt to be overall inefficient. ${ }^{80}$

Moreover, the rule eliminates the exercise of hold-out power by the counterparty and thus furthers the cause of asset stabilisation. The counterparty is given the full benefit of performance on the contract, and the debtor is able to maintain its asset pool's integrity.

Such a rule deviates from the normal liquidation priorities, where all unsecured creditors receive equal payment. ${ }^{81}$ But using this rule is necessary to recognise the going-concern value of the debtor in reorganisation. And counterparties know that such treatment is likely to occur, and are thus able to price their reduced hold-up rights ex ante. ${ }^{82}$

In short, clear distribution rules, whatever they may be, are all that is required. ${ }^{83}$ And stabilisation must occur to preserve asset value, not hold-up power. ${ }^{84}$

\footnotetext{
77 Assuming the debtor is insolvent.

78 Westbrook (1989), at p. 243.

79 Fuller and Perdue (1937), at pp. 384-85.

80 Adler (1992), at p. 455.

81 Hynes (2011), at p. 209.

82 See Tung (1996), at p. 1730.

83 Bebchuk and Fried (1997), at p. 1286.

84 See White (1994).
} 
This discussion also highlights the basic point that some parties have hold-up power in a reorganisation, and often the reorganisation process will need to simply acknowledge and move past that power to obtain true asset stabilisation.

\subsubsection{Monitoring the Estate}

More generally, to avoid the agency problems inherent in such a system of priority financing, an independent monitor or trustee ${ }^{85}$ must oversee the process. ${ }^{86}$ Such a monitor ensures that the new financing is not a disguised preference for specific claimants or management. ${ }^{87}$ This role can take the form of either a direct examination of the value of the debtor's assets, or of simply preserving the ability of parties to challenge the valuation issue at some point in the future. ${ }^{88}$

The monitor can also resolve disputes among new and incumbent lenders, particularly with regard to any rules that limit the priority of new financing.

Apart from these limited functions, a monitor is also the economical solution to the agency problems discussed above. All participants are confronted with skewed incentives and - when at the helm - with the ability to appropriate firm value. A monitor mitigates this problem, although imperfectly as incentives also undermine his impartiality.

Creditors might contract for the monitor, but his job description should be provided for in statute, including limits to his liability. This ensures that a monitor works for the benefit of all, but more importantly not for a specific creditor class. It also implies that the incentive scheme for a monitor should not be too highpowered, as this would skew his decision making. Limits to liability are needed in order to ensure an economically correct risk tolerance and to elicit experts to work as monitors. The selection of such a monitor can be market based, leaning on reputation effects, or can take place in courts.

The monitor might take the form of a committee with duties to a larger class of claimants. ${ }^{89}$ In such a case, the law likely must provide for the payment of the committee's expenses from either the debtor or the class. Otherwise the committee presents an obvious free-rider problem.

But instead of a committee, the monitor might be some other independent official. This avoids the common problem of conflicts among classes of claimants, a problem that many have argued has become more common with the advent of new, more complex financial instruments and trading strategies. ${ }^{90}$

In jurisdictions with court-based insolvency systems, the monitor might be subject to court oversight. The general challenge with such a structure is to avoid the creation of new agency problems that undermine the benefits of a monitor. If the

\footnotetext{
${ }^{85}$ Here, monitor is used generically, and not with specific reference to the Canadian monitor under the CCAA.

86 Westbrook (2004), at pp. 825-27.

87 Cf. Adler (1992), at pp. 446-55.

88 See McKenzie (2010), at p. 778.

89 See Bussel (1996), at p. 1579.

90 Baird and Rasmussen (2010) at p. 665.
} 
monitor is too 'pure' - that is, entirely disinterested in the case - the monitor's primary motivations may tend towards his own compensation, at the expense of an efficient reorganisation process.

\subsection{Asset Separation}

To achieve asset separation, a reorganisation system needs a mechanism that cleanly detaches a firm's liabilities, in all forms, from its assets. ${ }^{91}$ This could be achieved by a discharge provision, ${ }^{92}$ in the sense that upon fulfilling certain conditions all debt is wiped out and the debtor is allowed to resume operations unencumbered. ${ }^{93}$ But a discharge provision is not vital so long as the system provides that the new owner of the assets, which may be the post-bankruptcy firm, has clean title. ${ }^{94}$

This simply requires a legal mechanism for leaving all pre-distress debts behind, converting any obligation that would otherwise run with the assets into a tort-like claim for money damages. ${ }^{95}$ The key is that the process should not destroy value, or redistribute it in a way that is generally inefficient. ${ }^{96}$

In theory, asset separation can be achieved outside of bankruptcy. For example, under Delaware corporate law, the debtor firm could sell some part of its assets. ${ }^{97}$ The normal American rule is that an asset purchaser takes free from the seller's liabilities - the seller's creditors have their remedy against the sale proceeds. ${ }^{98}$

But there are several important exceptions to this basic rule. There are myriad forms of 'successor liability' that serve to reverse the presumption. ${ }^{99}$ And an asset sale might be challenged under fraudulent transfer law, particularly if the buyer fails to pay 'reasonably equivalent value'. 100

A corporate bankruptcy system replaces these rights, and other similar challenges to distressed asset sales, with a collective proceeding that serves to safeguard the same basic interests. Thus, while the process hands the buyer cleaner title, it must also ensure that doing so does not result in expropriation.

\footnotetext{
91 Keating (1994), at p. 546.

92 See generally McCoid (1996).

93 Brubaker (1997), at p. 1004.

94 See, e.g., In re Chrysler LLC, 576 F.3d 108, 119 (2d Cir. 2009) (upholding the sale of substantially all of 'Old Chrysler's' assets to 'New Chrysler' as '[c]onsistent with an underlying purpose of the Bankruptcy Code - maximizing the value of the bankrupt estate'), vacated as moot sub nom. Ind. State Police Pension Trust v. Chrysler LLC, 130 S. Ct. 1015 (2009).

95 See 11 U.S.C. $\$ 363(f)$ (stating trustee may sell $§ 363(a)(b)$ property 'free and clear of any interest in such property' subject to enumerated conditions and limitations); Warburton (2010), at p. 581.

96 See Jacoby and Janger (2014), at p. 914 ('[W]hen the ... leverage is used to alter the relative distribution, the sale is not Pareto optimal. Efficiency is being achieved at the expense of one or more holders of claims or interests.'); LoPucki and Doherty (2007) (arguing that American 363 sales result in lower recoveries for creditors than traditional plans).

97 Del. Gen. Corp. Code $§ 271$.

98 Marks v. Minnesota Mining \& Mfg. Co., 232 Cal. Rptr. 594 (Ct. App. 1986).

99 Franklin v. USX Corp., 105 Cal. Rptr. 2d 11 (Ct. App. 2001) (summarising exceptions).

1006 Del. C. $\S \S 1301-1311$.
} 
This suggests that separation also requires distribution rules. Payment of the claims against the debtor should proceed by clearly defined rules, but these rules need not be the absolute priority rule that so dominates Anglo-American discussions of insolvency. ${ }^{101}$ Instead, it is simply important that the rules are known ex ante, whatever they may be. ${ }^{102}$

Asset separation necessarily follows asset stabilisation, and the choices made during the stabilisation phase influence recoveries upon separation. As noted in the discussion of stabilisation, as part of that initial process the debtor (or the monitor/ trustee) will often pay creditors outside of the normal distribution rules. The debtor's discretion in this regard is checked by an oversight mechanism.

That is, the asset separation process must be conducted in a manner that will result in the highest possible proceeds. A neutral party - be it a judge or a trustee ${ }^{103}$ - is needed to ensure that this happens. ${ }^{104}$

Nonetheless, because the debtor's discretion involves a good deal of business judgment - something courts and other monitors are often ill-equipped to exercise this oversight is rightly apt to be 'light'. And in most instances oversight will ultimately rely on stakeholders to surface issues of concern, since the ultimate distribution to stakeholders will be influenced by decisions the debtor makes while stabilising his assets.

This then highlights the basic notion that notice, participation rights and oversight are also key attributes that must accompany any asset separation tool.

In general, the mechanics of any particular jurisdiction's asset separation instrument is apt to be highly dependent on the local property law. In the United States, property law is highly fractured: each state has its own law, while real and personal property are distinct areas of the law, and in many cases motor vehicles provide yet another source of relevant law.

An asset sale of a large business in the United States thus involves a high degree of transaction costs. Not surprisingly, the US corporate bankruptcy system seeks to overcome these costs by consolidating power over the asset transfer in a single bankruptcy judge. In jurisdictions with more streamlined property law, the incremental gains from adoption of specific US procedures are apt to be minimal.

The key goal of asset separation is to provide mechanisms to overcome barriers to asset transfers and attempts by individual creditors to appropriate value through hold-ups. Discharges and other provisions that 'cleanse' assets are obvious pieces of asset separation.

Other provisions, like those overturning contractual prohibitions on asset transfer, also have a role to play. ${ }^{105}$ After all, such prohibitions are often just a means for demanding a side payment in exchange for consent to the transaction. On

\footnotetext{
101 Norwest Bank Worthington v. Ahlers, 485 U.S. 197, 207-08 (1988); Coffee (1995), at p. 1458; LoPucki (1996), at p. 11.

102 See Gilmore (1963), at p. 1344.

103 Frank (1941), at p. 317 ('[R]eorganization is only in its superficial aspects litigation inter partis and fundamentally it is an administrative problem of business and finance.').

104 Morrison (2007), at p. 411.

10511 U.S.C. $\S 365(f)$.
} 
an individual basis, such side payments represent an allocation of gains amongst two parties. When aggregated across an entire firm, however, such payments represent friction costs that destroy going-concern value.

\section{The Non-Essential Elements of Corporate Bankruptcy}

Comparison of the foregoing with current Chapter 11, or any other similar corporate reorganisation system, will quickly reveal that much of the present law is not essential. ${ }^{106}$

For example, Chapter 11 contains a set of well-developed rules regarding reorganisation plans. Statutory provisions cover the solicitation of votes on such plans, ${ }^{107}$ the voting and classification rules, ${ }^{108}$ and the rule for judicial confirmation of plans. ${ }^{109}$ But is it really vital to have reorganisation plans?

The sale of the debtor's good assets to a new legal entity can preserve the goingconcern value of the assets. At that point, distribution of the sale proceeds could just as easily occur under a liquidation structure as under a plan. ${ }^{110}$

Arguably, the general distribution rules are not a necessary part of the reorganisation system, but rather a necessary part of the larger debtor-creditor system. All debtors and creditors need to know where they stand in any sort of collection action. ${ }^{111}$

Note also that asset separation and asset stability do not necessarily require anything like the American 'debtor in possession' system - which leaves incumbent management in control. ${ }^{112}$ Certainly, existing management might be better able to achieve these ends, but that is a question of degree and subject to much debate, and our goal is to delineate the essential. ${ }^{113}$

Although rules for a reorganisation plan are thus not essential to bankruptcy law, if for whatever reason participants want one, the essential element is the upholding of the previously announced distribution rules. Upholding the rules typically complicates the process as it requires valuation of the firm and its claims. ${ }^{114}$ The fact that this is needed, however, does not mean that it is needed to specify rules for this. The alternative - selling the assets - provides the setting against which any proposal is evaluated. ${ }^{115}$ Rules may reduce haggling costs via a reduction of potential conflicts,

\footnotetext{
106 Finkelstein (1993), at p. 2229 (arguing that many justifications for Chapter 11 are actually justifications for the automatic stay).

107 See generally Betker et al. (1999).

108 Skeel (1992), at pp. 525-26.

109 11 U.S.C. § 1129. See also Tung (1996), at pp. 1714-29.

110 See Baird (1987b), at p. 820; Jackson (1982), at p. 893; Mooney (2004), at p. 1053.

111 Warren (1987), at p. 792.

11211 U.S.C. § 1107(a); Harner (2011), at p. 499.

113 Armour et al. (2002), at pp. 1728-30. See also Couwenberg and Lubben (2013). In that paper we argue that a debtor-in-possession system provides an efficient incentive to file early for bankruptcy. This argument follows from an analysis of bankruptcy's shadow on managerial behaviour, it is, though, not essential for asset stabilisation or separation.

114 Skeel (1998), at p. 1377.

115 See Schwartz (2005), at pp. 1243-44.
} 
but experience in the United States shows that any delineation or adjustment therein creates room for redistributive actions and even costly lobbying of Congress. ${ }^{116}$ It does not follow therefore that such rules are efficiency enhancing, let alone essential.

Although economic cycles might diminish or even eliminate first- and secondbest buyers for distressed assets, ${ }^{117}$ it does not mean that rules for reorganisation are essential. To our minds, asset stabilisation and separation, however created, are the more important elements.

The argument that the reorganisation option is the solution to a lack of possibilities to sell is not necessarily valid. Even in a hypothetical sale the firm needs liquidity, which might not be forthcoming in a downturn. Selling to a secondbest buyer is then a better option. Furthermore, asset stabilisation does not require an immediate sale; it might be postponed, thus waiting for better options. Indefinite postponing creates adverse competitive effects, but will not happen easily as it will be difficult to secure financing for a new long-term strategy in bankruptcy. ${ }^{118}$

Plans are one possible collective solution to financial distress, but with sufficient financing and rules to govern hold-out problems, sales of the debtors' assets would seem to work just as well.

Creditors' committees were once considered vital to reorganisation, since small creditors were too often loath to incur the costs of participation. ${ }^{119}$ There is much wisdom in the basic idea of including creditors in the reorganisation, but the advent of modern finance has also called into question the notion that creditors' incentives are easily understood. ${ }^{120}$ As such, the ability of a committee to represent all unsecured creditors might be doubted, and we therefore do not deem such an instrument essential. ${ }^{121}$

Similarly, we doubt whether the various statutory priorities, ${ }^{122}$ caps on claims, ${ }^{123}$ rules for dealing with special contracts, ${ }^{124}$ special collateral, ${ }^{125}$ and special debtors are essential. ${ }^{126}$ Politically inevitable perhaps, but not essential.

\footnotetext{
116 Ayotte and Morrison (2009) and Roe and Tung (2013).

117 See Shleifer and Vishny (1992).

118 Some empirical studies on different systems show that asset sales can happen rather quickly, especially when compared to reorganisation procedures. See for non-US studies, e.g., Couwenberg and Jong (2008) and Thorburn (2000). However, for the US, the evidence is much less conclusive, see, e.g., Bris et al. (2006).

119 Adams (1993), at p. 614; Harner and Marincic (2011), at p. 765; Klee and Shaffer (1993), at p. 1041.

${ }^{120} \mathrm{Hu}$ and Black (2008), at pp. 728-35, and Lubben (2007), at p. 407.

${ }^{121}$ Cf. Lubben (2012b), at p. 470 (finding that committees contribute to the direct cost of reorganisation).

12211 U.S. C. $\S 507$. Statutory priorities just change the distributive scheme, might result in haggling costs, rent-seeking or even runs when ill-structured, but are not essential for asset stabilisation or separation.

12311 U.S.C. § 502(b). Capping claims alters the distribution, while settling especially large claims, e.g., the Texaco Pennzoil litigation, might lead to huge haggling costs. See Cutler and Summers (1988).

12411 U.S.C. $\$ \S 555,556,1113$.

12511 U.S.C. $\S 1110$. The exception might be cash collateral, which is especially at risk of expropriation. 11 U.S.C. $\S 363(a)$, (c).

12611 U.S.C. $\$ \S 1161-1174$ (railroad reorganisation provisions).
} 


\section{Conclusion}

Our goal is not to doubt the 'richness and elasticity' of corporate bankruptcy, particularly in the United States. ${ }^{127}$ There might be myriad policy reasons why any particular bankruptcy system might include particular features.

Our aim is instead to identify the minimum. We argue that there is a core of corporate bankruptcy - asset separation and asset stability - that parties cannot achieve alone, no matter how robust their contract law and drafting skills.

As such, it is this core that must be the basis for any sensible corporate insolvency system. Beyond that, features of the system are a matter of policy and politics.

Understanding where the core is, however, helps to focus policy makers' attention on the choices involved in structuring an insolvency system. And it leads away from the notion that Chapter 11 must be the standard against which all other laws are measured.

Open Access This article is distributed under the terms of the Creative Commons Attribution License which permits any use, distribution, and reproduction in any medium, provided the original author(s) and the source are credited.

\section{References}

Adams ES (1993) Governance in Chapter 11 reorganizations: reducing costs, improving results. Boston Univ Law Rev 73:581

Adler BE (1992) Bankruptcy and risk allocation. Cornell Law Rev 77:439

Adler BE (1993) Financial and political theories of American corporate bankruptcy. Stanf Law Rev $45: 311$

Altman EA (1993) Evaluating the Chapter 11 bankruptcy reorganization process. Columbia Bus Law Rev 1

Armour J et al (2002) Corporate ownership structure and the evolution of bankruptcy law: lessons from the United Kingdom. Vanderbilt Law Rev 55:1699

Ayotte KM, Morrison ER (2009) Creditor control and conflict in Chapter 11. J Leg Anal 1:511

Ayotte K, Skeel DA Jr (2006) An efficiency-based explanation for current corporate reorganization practice. Univ Chic Law Rev 73:425

Bainbridge SM (2003) Director primacy: the means and ends of corporate governance. Northwest Univ Law Rev 97:547

Baird DG (1987a) A world without bankruptcy. Law Contemp Probl 50:173

Baird DG (1987b) Loss distribution, forum shopping, and bankruptcy: a reply to Warren. Univ Chic Law Rev 54:815

Baird DG (1993) Revisiting auctions in Chapter 11. J Law Econ 36:633

Baird DG (1998) Bankruptcy's uncontested axioms. Yale Law J 108:573

Baird DG, Casey AJ (2013) No exit? Withdrawal rights and the law of corporate reorganizations. Columbia Law Rev 113:1

Baird DG, Jackson TH (1984) Corporate reorganization and the treatment of diverse ownership interests: a comment on adequate protection of secured creditors in bankruptcy. Univ Chic Law Rev 51:97

Baird DG, Jackson TH (1988) Bargaining after the fall and the contours of the absolute priority rule. Univ Chic Law Rev 55:738

Baird DG, Rasmussen RK (2002a) The end of bankruptcy. Stanf Law Rev 55:751

Baird DG, Rasmussen RK (2002b) Four (or five) easy lessons from Enron. Vanderbilt Law Rev 55:1787

Baird DG, Rasmussen RK (2003) Chapter 11 at twilight. Stanf Law Rev 56:673

127 Gelpern (2012), at p. 893. 
Baird DG, Rasmussen RK (2006) Private debt and the missing lever of corporate governance. Univ Pa Law Rev 154:1209

Baird DG, Rasmussen RK (2010) Antibankruptcy. Yale Law J 119:648

Baker CM (2010) Regulating the invisible: the case of over-the-counter derivatives. Notre Dame Law Rev 85:1287

Bebchuk LA (1988) A new approach to corporate reorganizations. Harv Law Rev 101:775

Bebchuk LA, Chang HF (1992) Bargaining and the division of value in corporate reorganization. J Law Econ Organ 8:253

Bebchuk LA, Fried JM (1997) The uneasy case for the priority of secured claims in bankruptcy: further thoughts and a reply to critics. Cornell Law Rev 82:1279

Ben-Ishai S, Lubben SJ (2012) Involuntary creditors and corporate bankruptcy. UBCL Rev 45:253

Betker BL et al (1999) 'Warm with sunny skies': disclosure statement forecasts. Am Bankruptcy Law J 73:809

Bratton WW Jr (1989) The 'nexus of contracts' corporation: a critical appraisal. Cornell Law Rev 74:407

Bris A, Welch I, Zhu N (2006) The costs of bankruptcy: Chapter 7 liquidation versus Chapter 11 reorganization. J Financ 59:1253

Brubaker R (1997) Bankruptcy injunctions and complex litigation: a critical reappraisal of non-debtor releases in Chapter 11 reorganizations. Univ Ill Law Rev 959

Buckley FH (1994) The American stay. South Calif Interdiscip Law J 3:733

Bussel DJ (1996) Coalition-building through bankruptcy creditors' committees. UCLA Law Rev 43:1547

Clark RC (1981) The interdisciplinary study of legal evolution. Yale Law J 90:1238

Coase RH (1937) The nature of the firm. Economica 4:386

Coffee JC Jr (1995) Class wars: the dilemma of the mass tort class action. Columbia Law Rev 95:1343

Countryman V (1985) The concept of a voidable preference in bankruptcy. Vanderbilt Law Rev 38:713

Couwenberg O, de Jong A (2006) It takes two to tango: an empirical tale of distressed firms and assisting banks. Int Rev Law Econ 26:429

Couwenberg O, de Jong A (2008) Costs and recovery rates in the Dutch liquidation-based bankruptcy system. Eur J Law Econ 26:105

Couwenberg O, Lubben SJ (2013) Solving creditor problems in the twilight zone: superfluous law and inadequate private solutions. Int J L Econ 34:61

Cutler DM, Summers LH (1988) The costs of conflict resolution and financial distress: evidence from the Texaco-Pennzoil litigation. RAND J Econ 19:157

Dickerson AM (2009) Privatizing ethics in corporate reorganizations. Minn Law Rev 93:875

Dodd EM Jr (1932) For whom are corporate managers trustees? Harv Law Rev 45:1145

Easterbrook FH (1990) Is corporate bankruptcy efficient? J Financ Econ 27:411

Eisenberg T, Sundgren S (1997) Is Chapter 11 too favorable to debtors? Evidence from abroad. Cornell Law Rev 82:1532

Eisenberg T, Tagashira S (1994) Should we abolish Chapter 11? The evidence from Japan. J Leg Stud 23:111

Finkelstein C (1993) Financial distress as a noncooperative game: a proposal for overcoming obstacles to private workouts. Yale Law J 102:2205

Fish JE (2010) The overstated promise of corporate governance. Univ Chic Law Rev 77:923

Frank J (1941) Epithetical jurisprudence and the work of the Securities and Exchange Commission in the administration of Chapter X of the Bankruptcy Act. N Y Univ Law Q Rev 18:317

Fuller LL, Perdue WR Jr (1937) The reliance interest in contract damages: 2. Yale Law J 46:373

Gelpern A (2012) Bankruptcy, backwards: the problem of quasi-sovereign debt. Yale Law J 121:888

Gilmore G (1963) The purchase money priority. Harv Law Rev 76:1333

Hansmann H, Kraakman R (1991) Toward unlimited shareholder liability for corporate torts. Yale Law J 100:1879

Hansmann H, Kraakman R (2000) The essential role of organizational law. Yale Law J 110:387

Hansmann H, Kraakman R (2001) The end of history for corporate law. Georget Law J 89:439

Harner MM (2011) The search for an unbiased fiduciary in corporate reorganizations. Notre Dame Law Rev 86:469

Harner MM, Marincic J (2011) Committee capture? An empirical analysis of the role of creditors' committees in business reorganizations. Vanderbilt Law Rev 64:749

Hart O (1995) Firms, contracts and financial structure. Clarendon Press, Oxford

Hu HTC, Black BS (2008) Equity and debt decoupling and empty voting II: importance and extensions. Univ Pa Law Rev 156:625 
Hu HTC, Westbrook JL (2007) Abolition of the corporate duty to creditors. Columbia Law Rev 107:1321 Hynes RM (2011) Reorganization as redemption. Va Law Bus Rev 6:183

Jackson TH (1982) Bankruptcy, non-bankruptcy entitlements, and the creditors' bargain. Yale Law J 91:857

Jackson TH, Scott RE (1989) On the nature of bankruptcy: an essay on bankruptcy sharing and the creditors' bargain. Va Law Rev 75:155

Jacoby MB, Janger EJ (2014) Ice cube bonds: allocating the price of process in Chapter 11 bankruptcy. Yale Law J 123:862

Keating D (1994) The continuing puzzle of collective bargaining agreements in bankruptcy. William Mary Law Rev 35:503

Klee KN, Shaffer KJ (1993) Creditors' committees under Chapter 11 of the Bankruptcy Code. SC Law Rev 44:995

Lawless RM, Warren E (2005) The myth of the disappearing business bankruptcy. Calif Law Rev 93:743

Lipson JC (2009) The shadow bankruptcy system. Boston Univ Law Rev 89:1609

Lipson JC (2011) Governance in the breach: controlling creditor opportunism. South Calif Law Rev 84:1035

LoPucki LM (1992) Strange visions in a strange world: a reply to professors Bradley and Rosenzweig. Mich Law Rev 91:79

LoPucki LM (1996) The death of liability. Yale Law J 106:1

LoPucki LM, Doherty JW (2007) Bankruptcy fire sales. Michigan Law Rev 106:1

LoPucki LM, Whitford WC (1990) Bargaining over equity's share in the bankruptcy reorganization of large, publicly held companies. Univ Pa Law Rev 139:125

LoPucki LM, Whitford WC (1993) Corporate governance in the bankruptcy reorganization of large, publicly held companies. Univ Pa Law Rev 141:669

Lubben SJ (2004) Railroad receiverships and modern bankruptcy theory. Cornell Law Rev 89:1420

Lubben SJ (2005) The 'new and improved' Chapter 11. Ky Law J 93:839

Lubben SJ (2007) Credit derivatives and the future of Chapter 11. Am Bankruptcy Law J 81:405

Lubben SJ (2009) Systemic risk and Chapter 11. Temple Law Rev 82:433

Lubben SJ (2012a) Transaction simplicity. Columbia Law Rev Sidebar 112:194

Lubben SJ (2012b) The Chapter 11 attorneys. Am Bankruptcy Law J 86:447

Markell BA (1991) Owners, auctions, and absolute priority in bankruptcy reorganizations. Stanf Law Rev 44:69

McCoid JC II (1996) Discharge: the most important development in bankruptcy history. Am Bankruptcy Law J 70:163

McKenzie TA (2010) Judicial independence, autonomy, and the bankruptcy courts. Stanf Law Rev 62:747

Mooney CW Jr (2004) A normative theory of bankruptcy law: bankruptcy as (is) civil procedure. Wash Lee Law Rev 61:931

Morrison ER (2007) Bankruptcy decision making: an empirical study of continuation bias in smallbusiness bankruptcies. J Law Econ 50:381

Myers SC (1977) Determinants of corporate borrowing. J Financ Econ 5:147

Ondersma C (2013) Shadow banking and financial distress: the treatment of 'money-claims' in bankruptcy. Columbia Bus Law Rev 79

Picker RC (1992) Voluntary petitions and the creditors' bargain. Univ Cincinnati Law Rev 61:519

Radin Max (1940) The nature of bankruptcy. Univ Pa Law Rev 89:1

Rasmussen RK (1992) Debtor's choice: a menu approach to corporate bankruptcy. Tex Law Rev 71:51

Resnick AN (2005) The future of the doctrine of necessity and critical-vendor payments in Chapter 11 cases. Boston Coll Law Rev 47:183

Roe MJ (1983) Bankruptcy and debt: a new model for corporate reorganization. Columbia Law Rev $83: 527$

Roe MJ (2011) The derivatives market's payment priorities as financial crisis accelerator. Stanf Law Rev 63:539

Roe MJ, Skeel DA (2010) Assessing the Chrysler bankruptcy. Mich Law Rev 108:727

Roe MJ, Tung F (2013) Breach bankruptcy priority: how rent-seeking upends the creditors' bargain. Va L Rev 99:1235

Romano R (1989) Answering the wrong question: the tenuous case for mandatory corporate laws. Columbia Law Rev 89:1599

Schwarcz SL (1999) Rethinking freedom of contract: a bankruptcy paradigm. Tex Law Rev 77:515 
Schwartz A (1998) A contract theory approach to business bankruptcy. Yale Law J 107:1807

Schwartz A (2005) A normative theory of business bankruptcy. Va Law Rev 91:1199

Scott RE (1986) Through bankruptcy with the creditors' bargain heuristic. Univ Chic Law Rev 53:690

Shleifer A, Vishny RW (1992) Liquidation values and debt capacity: a market equilibrium approach. J Financ 47:1343

Simkovic M (2009) Secret liens and the financial crisis of 2008. Am Bankruptcy Law J 83:253

Skeel DA Jr (1992) The nature and effect of corporate voting in Chapter 11 reorganization cases. Va Law Rev 78:461

Skeel DA Jr (1993) Markets, courts, and the brave new world of bankruptcy theory. Wis Law, Rev 465

Skeel DA Jr (1994) Rethinking the line between corporate law and corporate bankruptcy. Tex Law Rev $72: 471$

Skeel DA Jr (1998) An evolutionary theory of corporate law and corporate bankruptcy. Vanderbilt Law Rev 51:1325

Skeel DA Jr (2003) Creditors' ball: the 'new' new corporate governance in Chapter 11. Univ Pa Law Rev $152: 917$

Stout LA (2007) The mythical benefits of shareholder control. Va Law Rev 93:789

Thorburn KS (2000) Bankruptcy auctions: costs, debt recovery, and firm survival. J Financ Econ 58:337

Tung F (1996) Confirmation and claims trading. Northwest Univ Law Rev 90:1684

Tung F (2009) Leverage in the board room: the unsung influence of private lenders in corporate governance. UCLA Law Rev 57:115

Warburton AJ (2010) Understanding the bankruptcies of Chrysler and General Motors: a primer. Syracuse Law Rev 60:531

Warren E (1987) Bankruptcy policy. Univ Chic Law Rev 54:775

Warren E (1992) The untenable case for repeal of Chapter 11. Yale Law J 102:437

Warren E (1993) Bankruptcy policymaking in an imperfect world. Mich Law Rev 92:336

Warren E, Westbrook JL (2005) Contracting out of bankruptcy: an empirical intervention. Harv Law Rev 118:1197

Warren E, Westbrook JL (2009) The success of Chapter 11: a challenge to the critics. Mich Law Rev 107:603

Westbrook JL (1989) A functional analysis of executory contracts. Minn Law Rev 74:227

Westbrook JL (2000) A global solution to multinational default. Mich Law Rev 98:2276

Westbrook JL (2004) The control of wealth in bankruptcy. Tex Law Rev 82:795

White MJ (1994) Corporate bankruptcy as a filtering device: Chapter 11 reorganizations and out-of-court debt restructurings. J Law Econ Organ 10:268

Woo SP (2011) Regulatory bankruptcy: how bank regulation causes fire sales. Georget Law J 99:1615 